\title{
Non-destructive estimation of chlorophyll content of peanuts grown at different soil texture and salinity levels
}

\author{
Cihan KARACA®, Gulcin Ece ASLAN『, Begum POLAT ${ }^{\circledR}$, Dursun BUYUKTAS \\ Faculty of Agriculture, Department of Farm Structures and Irrigation, Akdeniz University, Antalya, Turkey \\ Corresponding author: C. Karaca, e-mail: cihankaraca@akdeniz.edu.tr \\ Author(s) e-mail: ecebacalan@akdeniz.edu.tr, btekelioglu@akdeniz.edu.tr,dbuyuktas@akdeniz.edu.tr
}

\section{ARTICLE INFO}

Received: June 24, 2021

Received in revised form: August 19, 2021

Accepted: August 23, 2021

\section{Keywords:}

Acetone extraction procedure

CCI

Chl-a

Chl-b

Chl-a+b

\begin{abstract}
Chlorophyll is a significant biochemical component and can be determined in the laboratory (destructive) and using various chlorophyll content measuring devices (non-destructive). In this study, destructive and non-destructive methods were used to determine chlorophyll content and compared in peanut (Arachis hypogaea cv. NC-7) grown under different soil texture and saline water applications. The experiment was carried out in a complete randomized block design in pots using two soil textures (clay-loam and sandy) and three irrigation water salinity $\left(0.7,2.1\right.$ and $\left.3.3 \mathrm{dS} \mathrm{m}^{-1}\right)$. While the chlorophyll contents (Chl-a , Chl$\mathrm{b}, \mathrm{Chl}-\mathrm{a}+\mathrm{b}, \mathrm{Chl}-\mathrm{a} / \mathrm{b})$ were determined with the acetone extraction procedure, which is classified as destructive methods under laboratory conditions, the Chlorophyll Content Index (CCI) values were measured with the hand-held chlorophyll meter device (Apogee CCM-200), which is a non-destructive method. While irrigation water salinity decreased all types of chlorophyll contents (Chl-a, Chl-b, Chl-a+b) $\left(\mathrm{mg} \mathrm{cm}^{-2}\right)$, it did not cause a statistical difference in $\mathrm{Chl}-\mathrm{a} / \mathrm{b}$. Linear and polynomial models were fitted between the different chlorophyll contents and the CCI values under different soil textures and saline water levels. Model performances were slightly better with the polynomial model compared to the linear model in all experimental treatments. Since the difference between model performances is small, it is recommended to use the linear model due to its ease of use. In addition, the total chlorophyll content can be safely estimated under saline conditions by using portable chlorophyll meters.
\end{abstract}

\section{Introduction}

Chlorophyll (Chl) is a significant biochemical component in the molecular system responsible for the photosynthesis of peanuts (Patane and Vibhute 2014). Chlorophyll a is the most abundant form of chlorophyll within photosynthetic organisms and, for the most part, gives plants their green color. There are also other forms of chlorophyll, coded b, $\mathrm{c}$, and d, enlarging the overall fluorescent signal (Patane and Vibhute 2014). The amount of chlorophyll $\mathrm{a}, \mathrm{b}$ and $\mathrm{a} / \mathrm{b}$ ratio in plants varies depending on species, organ (Perera and Smith 2013), agronomic practices, growth stage (Manolopoulou et al. 2016), drought stress (Khaleghi et al. 2012; Tezcan et al. 2018), salinity stress (Taibi et al. 2016), temperature stress (Martinazzo et al. 2012) and light intensity (Hazrati et al. 2016).

Various methods were developed to determine leaf chlorophyll content (Patane and Vibhute 2014). Of these methods, the spectrophotometric method is accepted as the most accurate and reliable method for determining leaf chlorophyll content (Parry et al. 2014). But the most important disadvantages of this method are time-consuming measurement process, destructive and requires well trained personnel. In recent years, nondestructive, in situ, optical techniques have become widely used to give a relative indication of leaf chlorophyll concentration (Parry et al. 2014) and provide a quick, reliable alternative to in vitro techniques (Wood et al. 1993). For this purpose, chlorophyll meters were developed which indirectly determines the amount of chlorophyll. These devices measure the transmittance of the red and infrared radiation emitted by leaves. The transmitted light is detected by the sensor as the analog signal and the inbuilt mini-processor converts this signal into SPAD or index (Chlorophyll Content Index (CCI)) by a defined arithmetic operation (Lunagaria et al. 2015). The CCM-200 uses absorbance to estimate the chlorophyll content in leaf tissue. Two wavelengths are used for absorbance determinations. One wavelength falls within the chlorophyll absorbance range while the other serves to compensate for mechanical differences such as tissue thickness. The CCM-200 measures the absorbance of both wavelengths and calculates a CCI value that is proportional to the amount of chlorophyll in the sample (Apogee 2017).

In more than 30 published papers to determine chlorophyll content for a large number of plants, the two types of chlorophyll meter developed by Minolta, (model SPAD-502) and Opti-Sciences, (model CCM-200) were commonly used (Parry et al. 2014). Chlorophyll contents were determined under water stress, salinity stress and fertilizer stress using various chlorophyll content measuring devices. Chlorophyll contents of various plants under salinity stress for beans (Beinsan et al. 2009), rice (Chandramohanan 2014), and soybean (Sabagh et al. 2015), and under water stress for olive (Khaleghi et al., 2012), cotton (Kazgöz Candemir and Ödemiş 2018), elaeagnus (Ahani 
et al. 2015), canola (Meskini-Vishkaee et al. 2015), sesamum (Baştuğ et al. 2016) strawberry (Ödemiş et al. 2020), and peanut (Ngulube et al. 2018) were determined using chlorophyll meters.

On the other hand, the performance of chlorophyll content measuring devices for olives (Khaleghi et al. 2012), Asian Pear (Ghasemi et al. 2011), grape (Filimon et al. 2016), paper birch (Richardson et al. 2002), and quercus (Silla et al. 2010) under different stress conditions was evaluated and compared with spectrophotometric measurements. In this study, it was aimed to determine the chlorophyll content of peanut (Arachis hypogaea cv. NC-7) grown under different soil texture (clay-loam and sandy) and salinity levels $\left(0.7,2.1\right.$ and $\left.3.3 \mathrm{dS} \mathrm{m}^{-1}\right)$ using the destructive method (spectrophotometer), and to compare them with the nondestructive method (CCI) for evaluating the performance of the nondestructive method.

\section{Materials and Methods}

The study was carried out at the Research and Application Farm of Agricultural Faculty at Akdeniz University between 27.05.2016 and 19.10.2016. The experimental area where the Mediterranean climate is prevailing was located at a latitude of $36^{\circ}, 53^{\prime}, 45^{\prime \prime} \mathrm{N}$, a longitude of $30^{\circ}, 38^{\prime}, 17^{\prime \prime} \mathrm{E}$, and an altitude of $30 \mathrm{~m}$. The temperature and relative humidity ranged between $18.3-33.1^{\circ} \mathrm{C}$ and $21.9-82.9 \%$ at the growing season in 2016 , respectively (MGM 2017).

The experiment was carried out in a complete randomized block design in pots using two soil textures, clay-loam and sandy, and began on 27.05.2016 with the planting of NC-7 (Arachis hypogaea cv. NC-7) peanut seeds. The crops were grown in $80 \mathrm{~L}$ plastic pots, 0.53 (upper diameter) $\times 0.41$ (bottom diameter) $\times 0.46$ (height) $\mathrm{m}$ deep, filled with clay-loam and sandy soils, and each pot had 4 plants. The physical characteristics of the soil were given in Table 1 .

The amount of irrigation water was based on soil water deficit in four days. To prevent salt accumulation in the pots, $20 \%$ extra irrigation as leaching water was applied. Ayers and Westcot (1985) reported threshold values corresponding to $0 \%$ $\left(\mathrm{EC}_{\mathrm{i}}=2.1 \mathrm{dS} \mathrm{m}^{-1}\right)$ and $50 \%\left(\mathrm{EC}_{\mathrm{i}}=3.3 \mathrm{dS} \mathrm{m}^{-1}\right)$ yield reduction for peanut. Depending on the study of Ayers and Westcot (1985), three different salinity levels $\left(\mathrm{EC}_{\mathrm{i}}=0.7,2.1,3.3 \mathrm{dS} \mathrm{m}^{-1}\right)$ were applied including the control treatment $\left(\mathrm{EC}_{\mathrm{i}}=0.7 \mathrm{dS} \mathrm{m}^{-1}\right)$. Saline irrigation water was prepared by mixing specific ratios of three different salts $\left(\mathrm{NaCI}, \mathrm{MgSO}_{4}\right.$ and $\left.\mathrm{CaCl}_{2}\right)$ in tap water.

To determine the chlorophyll content in different salinity treatments and soil textures, a total of 54 leaves, 3 from each replication were selected and marked. The chlorophyll content index (CCI) value in the marked leaves was measured by Apogee CCM-200 portable chlorophyll meter. Similar to Pereyra et al. (2014) all measurements were carried out early in the morning to avoid variations caused by the movement of chloroplasts during the course of the day. Following CCI measurement, the marked leaves were cut and leaf chlorophyll contents (Chlorophyll-a (Chl-a) $\left(\mathrm{mg} \mathrm{cm}^{-2}\right)$ and Chlorophyll-b (Chl-b) $\left(\mathrm{mg} \mathrm{cm}^{-2}\right)$ were determined by UV-V (PG T60 UV VIS) spectrophotometer in the laboratory conditions, then
Chlorophyll-a+b (Chl-a+b) (mg cm$\left.{ }^{-2}\right)$ and Chlorophyll-a/b (Chl$\mathrm{a} / \mathrm{b}$ ) were calculated. The acetone extraction method (Williams 1984) was used to directly determine leaf chlorophyll content. Since acetone extraction procedure is classified as destructive methods under laboratory conditions, for chlorophyll measurements, leaf samples were cut from the plant and analyzed only at the end of the experiment. As soon as the leaves were cut, they were transported to the laboratory in a thermal bag and chlorophyll content analysis was performed.

The experimental data were statistically analyzed by the general linear model (GLM). Means were compared using Duncan's Multiple Range Test, if necessary, to separate the means of the data at 0.05 level of significance. Regression analysis was performed between chlorophyll content (Chl-a, Chl-b Chl-a+b) obtained in vitro and CCI values measured in situ in order to determine the performance of chlorophyll meter at different salinity levels.

\section{Results and Discussion}

In order to evaluate the effect of soil textures (ST) and salinity level (SL) on Chl-a, Chl-b, Chl-a+b, Chl-a/b variance analysis results were given in Table 2.

The mean of Chl-a, Chl-b, Chl-a+b, and CCI decreased due to salinity stress. Compared to the control treatments $(0.7$ $\mathrm{ds}^{-1}$ ), the Chl-a content decreased by $37.9 \%$ and $62.1 \%$ in the $2.1 \mathrm{ds} \mathrm{m}^{-1}$ and $3.3 \mathrm{ds} \mathrm{m}^{-1}$ treatments, respectively, while the Chl-b content decreased by $32.8 \%$ and $58.0 \%$, respectively. (Table 2). Because previous studies (Jamil et al. 2007; Sabagh et al. 2015) showed that salt stress causes an increase in the chlorophyll-degrading enzyme (chlorophyllase), thereby inducing the destruction of the chloroplast structure and instability of the pigment-protein complexes. Since salts tend to attach to clay particles in the soil, salt accumulation occurs more in clay soils than in sandy soils under the same conditions (IAARD 2008). Considering these two conditions, it would be expected that the amount of chlorophyll would be low since salt accumulation was high in clay soils. However, this research showed that the mean of Chl-a, Chl-b, Chl-a+b and CCI contents were higher in clay-loam soil than sandy soil. This phenomenon can be explained by the relationship of soil texture with plant nutrients and water. Because clay soils have finer particles that can hold soil water and nutrients better than sandy soil (Dou et al. 2016). For this reason, in this study, crop development was positively affected and increased chlorophyll content due to the fact that crops benefited more from water and nutrients in clay soil.

Different levels of irrigation water salinity and soil textures did not affect the ratio of Chl-a and Chl-b (Chl-a/b) statistically (Table 2). The Chl-a/b ranged from 1.37 to 3.48, depending on the different treatments (Data not shown). Banks and Eskins (1981) reported that the ratio of Chl-a and Chl-b was between 2.5 and 3.5 in 5 different peanut varieties. However, Monge et al. (1987) declared that this value for peanuts varied between approximately 1.2 and 2.0. The difference between $\mathrm{Chl}-\mathrm{a} / \mathrm{b}$ values in different experiments shows that this ratio is affected by many environmental factors and variety differences.

Table 1. Physical characteristics of soils used in the experimental pots

\begin{tabular}{|c|c|c|c|c|c|c|c|c|c|}
\hline No & $\begin{array}{c}\text { Sand } \\
(\%)\end{array}$ & $\begin{array}{l}\text { Silt } \\
(\%)\end{array}$ & $\begin{array}{l}\text { Clay } \\
(\%)\end{array}$ & Texture Class & $\begin{array}{c}\text { Field Capacity } \\
(\%)\end{array}$ & $\begin{array}{c}\text { Permanent wilting } \\
\text { point }(\%)\end{array}$ & $\begin{array}{c}\text { Bulk density } \\
\left(\mathrm{g} \mathrm{cm}^{-3}\right)\end{array}$ & pH & $\begin{array}{c}\mathbf{E C} \\
\left(\mathbf{d S} \mathbf{~ m}^{-1}\right)\end{array}$ \\
\hline 1 & 23.7 & 27.6 & 48.7 & Clay-Loam & 27 & 13.8 & 1.20 & 6.9 & 0.989 \\
\hline 2 & 94 & 1.5 & 4.5 & Sandy & 8.5 & 2 & 1.45 & 7.9 & 0.293 \\
\hline
\end{tabular}


Table 2. Effect of different soil textures and salinity levels on Chl-a, Chl-b, Chl-a+b, Chl-a/b and CCI content

\begin{tabular}{|c|c|c|c|c|c|c|}
\hline \multirow{7}{*}{$\begin{array}{c}\text { Chl-a } \\
\left(\mathrm{mg} \mathrm{cm}^{-2}\right)\end{array}$} & \multirow{2}{*}{ Soil texture } & \multicolumn{3}{|c|}{ Salinity level } & \multirow{2}{*}{$P>F$} & \multirow{2}{*}{ Mean of ST } \\
\hline & & $0.7\left(\mathrm{ds} \mathrm{m}^{-1}\right)$ & $2.1\left(\right.$ ds m$\left.^{-1}\right)$ & $3.3\left(\mathrm{ds} \mathrm{m}^{-1}\right)$ & & \\
\hline & Clay-Loam & ${ }^{\ddagger} 0.38 \mathrm{Aa}$ & $0.22 b$ & $0.14 c$ & $* *$ & $0.25 \mathrm{~A}$ \\
\hline & Sandy & $0.20 B$ & 0.15 & 0.08 & ns & 0.14 B \\
\hline & $\mathbf{P}>\mathbf{F}$ & $*$ & ns & ns & & \\
\hline & Mean of SL & $\dagger 0.29 \mathrm{a}$ & $0.18 \mathrm{~b}$ & $0.11 \mathrm{c}$ & & \\
\hline & Significance & Soil Texture (ST): ** & Salinity Level (SL): ** & * ST x SL: $n s$ & & \\
\hline \multirow{6}{*}{$\begin{array}{c}\text { Chl-b } \\
\left(\mathrm{mg} \mathrm{cm}^{-2}\right)\end{array}$} & & $0.7\left(\mathrm{ds} \mathrm{m}^{-1}\right)$ & $2.1\left(\mathrm{ds} \mathrm{m}^{-1}\right)$ & $3.3\left(\right.$ ds m$\left.^{-1}\right)$ & $\mathbf{P}>\mathbf{F}$ & Mean of ST \\
\hline & Clay-Loam & ${ }^{ \pm} 0.140 a$ & $0.093 b$ & $0.063 b$ & $* *$ & $\dagger 0.099$ A \\
\hline & Sandy & $0.099 a$ & $0.062 a b$ & $0.039 \mathrm{~b}$ & $*$ & 0.067 B \\
\hline & $\mathbf{P}>\mathbf{F}$ & ns & ns & ns & & \\
\hline & Mean of SL & $\dagger 0.119$ a & 0.080 b & $0.050 \mathrm{c}$ & & \\
\hline & Significance & Soil Texture (ST): ** & Salinity Level (SL): ** & $S T \times S L: n s$ & & \\
\hline \multirow{6}{*}{$\begin{array}{l}\mathrm{Chl}-\mathrm{a}+\mathrm{b} \\
\left(\mathrm{mg} \mathrm{cm}^{-2}\right)\end{array}$} & & $0.7\left(\mathrm{ds} \mathrm{m}^{-1}\right)$ & $2.1\left(\mathrm{ds} \mathrm{m}^{-1}\right)$ & $3.3\left(\mathrm{ds} \mathrm{m}^{-1}\right)$ & $\mathbf{P}>\mathbf{F}$ & Mean of ST \\
\hline & Clay-Loam & ${ }^{£} 0.52 a$ & $0.31 b$ & $0.21 b$ & $* *$ & $\dagger 0.35 \mathrm{~A}$ \\
\hline & Sandy & 0.30 & 0.22 & 0.12 & ns & 0.21 B \\
\hline & $\mathbf{P}>\mathbf{F}$ & ns & ns & ns & & \\
\hline & Mean of SL & ${ }^{\dagger} 0.41 \mathrm{a}$ & $0.26 \mathrm{~b}$ & $0.16 \mathrm{c}$ & & \\
\hline & Significance & Soil Texture (ST): ** & Salinity Level (SL): ** & $S T \times S L: n s$ & & \\
\hline \multirow{6}{*}{ Chl-a/b } & & $0.7\left(\mathrm{ds} \mathrm{m}^{-1}\right)$ & $2.1\left(\mathrm{ds} \mathrm{m}^{-1}\right)$ & $3.3\left(\mathrm{ds} \mathrm{m}^{-1}\right)$ & $\mathbf{P}>\mathbf{F}$ & Mean of ST \\
\hline & Clay-Loam & 2.72 & 2.31 & 2.31 & ns & $\mathbf{2}^{2.45}$ \\
\hline & Sandy & 1.99 & 2.49 & 2.02 & ns & 2.16 \\
\hline & $\mathbf{P}>\mathbf{F}$ & $\mathrm{ns}$ & $\mathrm{ns}$ & ns & & \\
\hline & Mean of SL & 2.36 & 2.40 & 2.16 & & \\
\hline & Significance & Soil Texture (ST): ns & Salinity Level (SL): ns & $S T \times S L: n s$ & & \\
\hline \multirow{6}{*}{$\mathrm{CCI}$} & & $0.7\left(\mathrm{ds} \mathrm{m}^{-1}\right)$ & $2.1\left(\mathrm{ds} \mathrm{m}^{-1}\right)$ & $3.3\left(\mathrm{ds} \mathrm{m}^{-1}\right)$ & $\mathbf{P}>\mathbf{F}$ & Mean of ST \\
\hline & Clay-Loam & ${ }^{£} 17.1 \mathrm{Aa}$ & $11.6 \mathrm{Ab}$ & $10.5 \mathrm{Ab}$ & $* *$ & $\dagger 12.8 \mathrm{~A}$ \\
\hline & Sandy & $10.3 \mathrm{~B}$ & $8.3 B$ & $7.0 \mathrm{~B}$ & ns & 8.6 B \\
\hline & $\mathbf{P}>\mathbf{F}$ & $*$ & $*$ & $*$ & & \\
\hline & Mean of SL & ${ }^{\dagger} 13.4 \mathrm{a}$ & $10.0 \mathrm{~b}$ & $8.8 \mathrm{c}$ & & \\
\hline & Significance & Soil Texture (ST): ** & Salinity Level (SL): ** & $S T \times$ x $S L: \mathrm{ns}$ & & \\
\hline
\end{tabular}

${ }^{£}:$ In the italicized section, means followed by the different small letters in each row or capital letters in each column are significantly different at $5 \%$ level by Duncan test. : In the bold section, means followed by the different small letters in each row or capital letters in each column are significantly different at $5 \%$ level by Duncan test. *: $P<0.05$ (significant); **: $P<0.01$ (highly significant). ns: non-significant.

Linear and polynomial functions were fitted to estimate Chl-a, Chl-b, Chl-a+b content from portable chlorophyll meter (CCI) measurements in sandy and clay-loam soils. The mathematical equations of linear and polynomial functions and the determination coefficients $\left(\mathrm{R}^{2}\right)$ of these equations were given in Figure 1.

The relationship between CCI and chlorophyll content was described linearly in Asian pear tree by Ghasemi et al. (2011), in wheat by Lunagaria et al. (2015), in sugar maple by Van Den Berg and Perkins (2004), and was described non-lenearly by Richardson et al. (2002) in paper birch. Parry et al. (2014), on the other hand, studied 30 different studies and examined the relationship between CCI and chlorophyll content for 22 different plants and this study highlights the enormous differences in chlorophyll distribution among species and even within species.

There was a high relationship between CCI and all chlorophyll contents in both soil textures $\left(\mathrm{R}^{2}>0.80\right)$ (Figure 1). Depending on the increase in chloroplast uniformity, the efficiency of red light absorption increases (Parry et al. 2014). Parry et al. (2014) reported that the transmission of light through a leaf is affected by pigment concentration and pigment spatial distribution in leaves. The authors also claimed that nonuniform chlorophyll distribution caused decreases in transmission of light at lower chlorophyll concentrations. Therefore in each chlorophyll content, $\mathrm{R}^{2}$ values of linear and polynomial curves of clay soils were higher compared to sandy soils.

When the different regression fitted models (linear and polynomial) were examined, the $\mathrm{R}^{2}$ of the polynomial equations showed higher performances for all soil and chlorophyll content types. On the other hand, the $\mathrm{R}^{2}$ of all fitted model equations was very close to each other in the same treatments. For this reason, it is recommended to use the linear equation to determine the chlorophyll contents because it is easier to use.

\section{Conclusion}

This study was conducted to determine the effects of soil texture and salinity level on the chlorophyll content in peanuts. In addition, the determination coefficients of linear and polynomial fitted curves were determined between the chlorophyll contents obtained by destructive and nondestructive methods. In this study, the chlorophyll contents (Chl-a, Chl-b, Chl-a+b and CCI) of peanuts varied statistically depending on the salinity level of the irrigation water and soil texture. The results showed that increasing salinity levels decreased the chlorophyll contents. In addition, the chlorophyll content on clay-loam soil treatments was higher compared to 


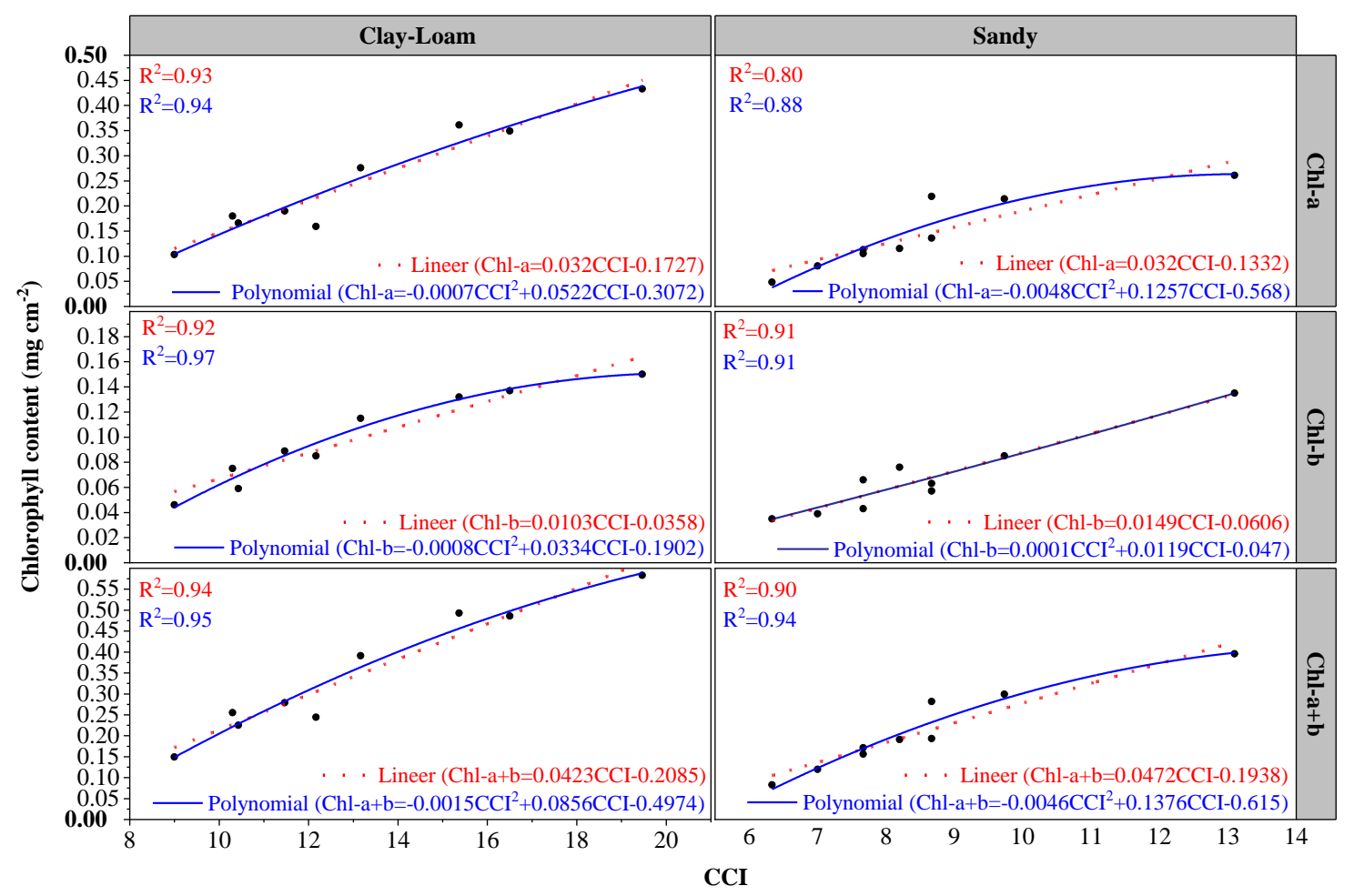

Figure 1. Equations based on linear and polynomial fitted curves between Chl-a, Chl-b and Chl-a+b and CCI values and the coefficients of determination of these equations.

sandy soil. The linear and polynomial models had high performance in all soil textures and chlorophyll contents. Although the polynomial model showed higher performance compared to the linear model, it is recommended to use the linear model to estimate CCI because there is no big difference in performance and it is easier to use. According to these results, the total chlorophyll content can be easily and safely estimated under the saline conditions by using the portable chlorophyll meter.

\section{References}

Ahani H, Jalilvand H, Vaezi J, Sadati SE (2015) Effects of different water stress on photosynthesis and chlorophyll content of Elaeagnus Rhamnoides. Iranian Journal of Plant Physiology 5: 1403-1410.

Apogee (2017) CCM-200 Chlorophyll Content Meter Web Manual. Apogee Instrument.

Ayers AS, Westcot DW (1985) Water Quality for Agriculture. FAO Irrigation and Drainage Paper 20, Rome.

Banks DJ, Eskins K (1981) Analysis of normal and mutant peanut chloroplast pigments by liquid chromatography. Peanut Science 1: $40-42$.

Baştuğ R, Karaca C, Büyüktaş D, Aydınşakir K, Dinç N (2016) The effects of deficit irrigation on water use, yield and quality properties of sesame (Sesamum indicum L.) grown in lysimeters. In 13. Ulusal Kültürteknik Kongresi. Antalya, Turkey, pp. 256-266. (In Turkish)

Beinsan C, Camen D, Sumalan R, Babau M (2009) Study concerning salt stress effect on leaf area dynamics and chlorophyll content in four bean local landraces from Banat area. In 44th Croatian \& 4th International Symposium on Agriculture. Opatija, Croatia, pp. 416419.

Van Den Berg AK, Perkins TD (2004) Evaluation of a portable chlorophyll meter to estimate chlorophyll and nitrogen contents in sugar maple (Acer saccharum Marsh.) leaves. Forest Ecology and Management 200: 113-117.

Chandramohanan KT (2014) A study on the effect of salinity stress on the chlorophyll content of certain rice cultivars of Kerala State of India. Agriculture, Forestry and Fisheries 3: 67.

Dou F, Soriano J, Tabien RE, Chen K (2016) Soil texture and cultivar effects on rice (Oryza sativa, L.) grain yield, yield components and water productivity in three water regimes. PLoS ONE 11: 1-12.

Filimon RV, Rotaru L, Filimon RM (2016) Quantitative investigation of leaf photosynthetic pigments during annual biological cycle of Vitis vinifera L. table grape cultivars. South African Journal for Enology and Viticulture 37: 1-14.

Ghasemi M, Arzani K, Yadollahi A, Ghasemi S, Sarikhani Khorrami S (2011) Estimate of leaf chlorophyll and nitrogen content in Asian Pear (Pyrus serotina Rehd.) by CCM-200. Notulae Scientia Biologicae 3: 91-94.

Hazrati S, Tahmasebi-Sarvestani Z, Modarres-Sanavy SAM, MokhtassiBidgoli A, Nicola S (2016) Effects of water stress and light intensity on chlorophyll fluorescence parameters and pigments of Aloe vera L.. Plant Physiology and Biochemistry 106: 141-148.

IAARD (2008) A Practical Guide To Restoring Agriculture After A Tsunami. In Indonesian Agency for Agricultural Research and Development, Indonesia and NSW Department of Primary Industries.

Jamil M, Rehman SU, Kui JL, Jeong MK, Kim HS, Eui SR (2007) Salinity reduced growth PS2 photochemistry and chlorophyll content in radish. Scientia Agricola 64: 111-118.

Kazgöz Candemir D, Ödemiş B (2018) Effects of foliar sulfur applications in reducing water stress applied to the cotton plant (Gossypium hirsutum L.) during different development (In Turkish) periods. Derim 35: 161-172.

Khaleghi E, Arzani K, Moallemi N, Barzegar M (2012) Evaluation of chlorophyll content and chlorophyll fluorescence parameters and relationships between chlorophyll a, b and chlorophyll content 
index under water stress in Olea europaea cv. Dezful. International Scholarly and Scientific Research and Innovation 6: 2108-2111.

Lunagaria MM, Patel HR, Pandey V (2015) Evaluation and calibration of noninvasive leaf chlorophyll meters for wheat. Journal of Agrometeorology 17: 51-54.

Manolopoulou E, Varzakas T, Petsalaki A (2016) Chlorophyll determination in green pepper using two different extraction methods. Current Research in Nutrition and Food Science Journal 4: $52-60$

Martinazzo EG, Ramm A, Bacarin MA (2012) The chlorophyll a fluorescence as an indicator of the temperature stress in the leaves of Prunus persica. Brazilian Journal of Plant Physiology 24: 237 246.

Meskini-Vishkaee F, Mohammadi MH, Neyshabouri MR, Shekari F (2015) Evaluation of canola chlorophyll index and leaf nitrogen under wide range of soil moisture. International Agrophysics 29: 83-90.

MGM (2021) General Meteorological Statistics of Provinces. Turkish State Meteorological Service. https://www.mgm.gov.tr/veridegerlendirme/il-ve-ilceler-

istatistik.aspx?k=A\&m =ANTALYA. Accessed 7 June, 2021.

Monge E, Val J, Heras L, Abadia J (1987) Photosynthetic Pigment Composition of Higher Plants Grown under Iron Stress. In: Biggins J (Ed.), Progress in Photosynthesis Research: Proceedings of the VIIth International Congress on Photosynthesis Providence, Rhode Island, USA, Springer Netherlands, Dordrecht, pp. 201-204.

Ngulube M, Mweetwa AM, Phiri E, Muriu SC, Chalwe H, Shitumbanuma V, Brandenburg RL (2018) Effects of biochar and gypsum soil amendments on groundnut (Arachis hypogaea L.) dry matter yield and selected soil properties under water stress. African Journal of Agricultural Research 13: 1080-1090.

Ödemiş B, Kazgöz Candemir D, Evrendilek F (2020) Responses to drought stress levels of strawberry grown in greenhouse condiations. Hortic. Studies 37: 113-122.

Parry C, Blonquist JM, Bugbee B (2014) In situ measurement of leaf chlorophyll concentration: Analysis of the optical/absolute relationship. Plant, Cell and Environment 37: 2508-2520.
Patane P, Vibhute A (2014) Chlorophyll and nitrogen estimation techniques: A Review. International Journal of Engineering Research and Reviews 2: 2348-697.

Perera CO, Smith B (2013) Technology of Processing of Horticultural Crops. In: Handbook of Farm, Dairy and Food Machinery Engineering. London, pp. 259-315.

Pereyra MS, Davidenco V, Núñez S, Argüello JA (2014) Chlorophyll content estimation in oregano leaves using a portable chlorophyll meter: relationship with mesophyll thickness and leaf age. Agronomía and Ambiente 34: 77-84.

Richardson AD, Duigan SP, Berlyn GP (2002) An evaluation of noninvasive methods to estimate foliar chlorophyll content. New Phytologist 153: 185-194.

Sabagh AEL, Omar AE, Saneoka H, Barutçular C (2015) Comparative physiological study of soybean (Glycine Max L.) cultivars under salt stress. Yuzuncu Yil University Journal of Agricultural Sciences 25: 269-284.

Silla F, González-Gil A, González-Molina ME, Mediavilla S, Escudero A (2010) Estimation of chlorophyll in quercus leaves using a portable chlorophyll meter: effects of species and leaf age. Annals of Forest Science 67: 108-108.

Taibi K, Taïbi F, Ait Abderrahim L, Ennajah A, Belkhodja M, Mulet JM (2016) Effect of salt stress on growth, chlorophyll content, lipid peroxidation and antioxidant defence systems in Phaseolus vulgaris L.. South African Journal of Botany 105: 306-312.

Tezcan A, Aslan GE, Kaman H, Can M, Sayici A, Gökçen U, Ekizoğlu $\mathrm{H}$ (2018) Assessing different irrigation regimes regarding chlorophyll content of the sweet bell pepper. Journal of Agriculture and Ecology Research International 15: 1-7.

Williams S (1984) Official Methods of Analysis of the Association of Official Analytical Chemists (14th ed.). In Association of Analytical Communities, USA.

Wood CW, Reeves DW, Himelrick DG (1993) Relationships between chlorophyll meter readings and leaf chlorophyll concentration, $\mathrm{N}$ status, and crop yield: A review. Proceedings of the Agronomy Society of New Zealand 23: 1-9. 